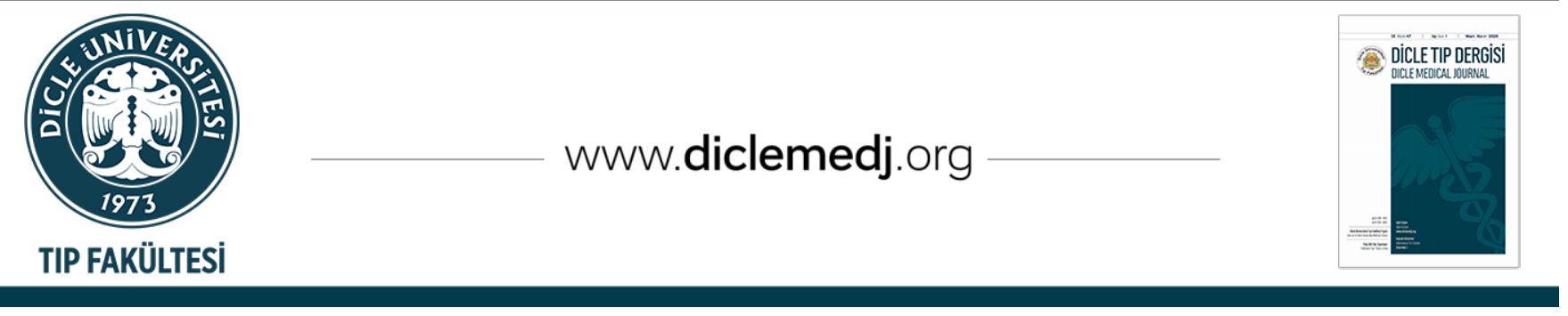

Original Article / Özgün Araştırma

\title{
Frequency of Brucellosis and Hepatitis B Virus Seropositivity in Patients with Chronic Lymphocytic Leukemia
}

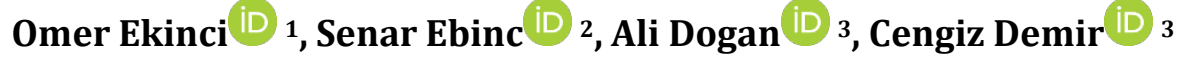 \\ 1 Department of Hematology, Faculty of Medicine, Firat University, Elazı̆̆, Turkey \\ 2 Department of Medical Oncology, Faculty of Medicine, Dicle University, Diyarbakır, Turkey \\ 3 Department of Hematology, Faculty of Medicine, Yüzüncü Yıl University, Van, Turkey
}

Received: 29.05.2020; Revised: 25.08.2020; Accepted: 30.08.2020

\begin{abstract}
Objective: Patients with chronic lymphocytic leukemia (CLL) show defective cellular and humoral immune responses. Although such immune failure is known to be associated with an increase in the frequency of particularly gram-positive and -negative bacterial infections, data on the increase in the frequency of zoonoses such as brucellosis and viral infections such as the hepatitis B virus (HBV) are inconclusive. This study aims to investigate the frequency of brucellosis and HBV seropositivity in patients diagnosed with CLL.
\end{abstract}

Methods: Patients followed-up for CLL between 2005 and 2019 were evaluated. Results of patients who were tested for HBsAg and anti-HBs serology using the ELISA assay and for brucellosis using the serum agglutination (Wright) test were recorded. Demographic data and laboratory results of all patients included in the study were evaluated.

Results: This study included 188 patients diagnosed with CLL, of whom 56 (29.8\%) were female and 132 (70.2\%) were male. Median age was 62 (33-92) years. Complete blood count parameters at diagnosis were as follows: median leukocyte count, 54.4×109/L (5.1$312.3 \times 109 / \mathrm{L})$; median lymphocyte count, $42.3 \times 109 / \mathrm{L}(2.8-296.8 \times 109 / \mathrm{L})$; median platelet count, 148×109/L (86.3-342.3×109/L); median hemoglobin level, $13.4 \mathrm{~g} / \mathrm{dL}(8.5-16.9 \mathrm{~g} / \mathrm{dL})$. HBsAg and anti-HBs were tested in 142 patients. A total of $16(11.27 \%)$ patients were HBsAg-positive; with 5 (3.52\%) positive cases in females and 11 (7.75\%) in males. A total of 105 (73.95\%) patients were antiHBs-positive; with $32(22.54 \%)$ positive cases in females and $73(51.41 \%)$ in males. Wright agglutination test was performed on 82 patients. A total of $4(4.88 \%)$ patients reacted positively to the Wright test; with $3(3.66 \%)$ positive cases in females and 1 (1.22\%) in males.

Conclusion: Compared with the epidemiological studies conducted in the same region; the rate of positive reactions to the Wright agglutination test was consistent with the literature data; however, a higher rate of HBsAg positivity was determined. This may be linked to the increase in the risk of HBV transmission due to the immune defect caused by CLL or the immunosuppressive picture induced by the medication used in the treatment, or viral reactivation.

Keywords: Chronic lymphocytic leukemia, Brucellosis, Hepatitis B seroprevalence

DOI: $10.5798 /$ dicletip.799950

Correspondence/Yazışma Adresi: Omer Ekinci, Fırat University Faculty of Medicine, Department of Hematology, Elazığ, Turkey e-mail: dromere@hotmail.com 


\section{Kronik Lenfositik Lösemi Hastalarında Bruselloz ve Hepatit B Virüsü Seropozitiflik Sıklığı}

\section{Öz}

Amaç: Kronik lenfositik lösemi (KLL) hastalarında hücresel ve humoral immün yanıtta defektler görülmektedir. Bu immun yetmezlik durumda özellikle gram pozitif ve negatif bakteriyel enfeksiyon sıklığının arttığı bilinmekte, ancak bruselloz gibi zoonozların ve hepatit B virüsü (HBV) gibi viral enfeksiyonların artışı ile ilgili bilgiler net değildir. Bu çalışmada KLL tanılı hastalarda bruselloz ve HBV seropozitiflik sıklığını araştırmayı amaçladık.

Yöntemler: 2005-2019 yılları arasında takip edilen KLL tanılı hastalar değerlendirildi. Tüm hastalar içerisinde; HBsAg ve anti-HBs serolojisi için ELISA testi, bruselloz için serum aglütinasyon (Wright) testi kullanılan hastaların test sonuçları kaydedildi. Çalışmaya alınan tüm hastaların demografik verileri ve laboratuvar sonuçları değerlendirildi.

Bulgular: KLL tanılı 188 hasta çalışmaya dâhil edildi. Bunların 56 (\%29,8)'sı kadın, 132 (\%70,2)'si erkek idi. Hastaların medyan yaşı 62 (33-92) idi. Tanı anındaki tam kan sayım parametreleri olarak; medyan lökosit sayısı 54.4×109/L (5.1-312.3×109/L); medyan lenfosit sayısı 42.3×109/L (2.8-296.8×109/L); medyan trombosit sayısı 148×109/L (86.3-342.3×109/L); medyan hemoglobin düzeyi $13.4 \mathrm{~g} / \mathrm{dL}$ (8.5-16.9 g/dL) idi. Hastaların 142'sine HBsAg ve anti-HBs bakılmıștı. HBsAg kadınların 5(\%3,52)'inde, erkeklerin 11 $(\% 7,75)$ 'inde, toplamda 16 (\%11,27) kişide pozitif idi. Anti-HBs antikoru kadınların $32(\% 22,54)$ 'sinde, erkeklerin 73 (\%51,41)'ünde, toplamda ise $105(73,95)$ kișide pozitifti. Wright aglütinasyon testi 82 kişide bakılmıștı. Kadınların $3(\% 3,66)$ ünde, erkeklerin 1 $(\% 1,22)$ 'inde, toplamda $4(\% 4,88)$ kişide Wright testi pozitif saptandı.

Sonuç: Aynı bölgede yapılan epidemiyolojik çalışmalar ile karşılaştırıldığında; Wright aglütinasyon testi pozitiflik oranı literatürde sunulan veriler ile uyumlu idi, ancak HBsAg pozitiflik oranı ise çalışmalarda sunulandan daha yüksek olarak izlendi. Bu durumun KLL nedeni ile oluşan immün defekt veya tedavide kullanılan ilaçların oluşturdukları immünsüpresif tablonun HBV bulaş riskini artırması veya viral reaktivasyon ile ilişkili olabileceği düşünüldü.

Anahtar kelimeler: Kronik lenfosik lösemi, Bruselloz, Hepatit B seroprevalansı.

\section{INTRODUCTION}

Chronic lymphocytic leukemia (CLL) is a disease characterized by an increase in mature neoplastic lymphocytes in tissues with a lymphoid component, such as peripheral blood, bone marrow, lymph node, spleen and liver ${ }^{1}$. Although it is usually initially asymptomatic, patients can manifest clinical symptoms such as fever, fatigue, and recurrent infections. Presence of lymphocytosis in the complete blood count is a prerequisite for the diagnosis, while lymphadenopathy or hepatosplenomegaly are encountered in 40$50 \%$ of patients ${ }^{2}$. The prognosis of CLL is quite variable due to the biological and clinical differences related to the disease and the variability in CD5 expression ${ }^{3}$. While some patients demonstrate an indolent course, others manifest a rapid course with no response to medication ${ }^{4}$.

Brucellosis is a disease caused by the Brucella bacteria that predominantly affects herbivores, and animal-to-human transmission is usually via contact with infected animals and consumption of infected milk and dairy products 5 . Species that act as causative agents in humans include B. melitensis, B.abortus, B. suis, and B. canis. B. melitensis, which predominantly infects sheep and goat, is typically transmitted to humans via consumption. Meanwhile, B. Abortus is mainly transmitted to humans from cattle and it is more frequent in regions where animal husbandry is common. B. Suis and B. Canis are transmitted to humans from pigs and dogs, respectively, and cause sporadic infections in those who work in contact with these animals ${ }^{6}$. The disease typically presents with fatigue, lack of appetite, body aches and fever. Although Brucellosis more commonly involves the locomotor system, it can sometimes present with isolated visceral organ infections or a picture that resembles the symptoms of lymphoid malignancies ${ }^{7}$.

The hepatitis B virus (HBV), which is transmitted parenterally, is a common infection 
throughout the world. Nearly 250 million people around the world are thought to be hepatitis B surface antigen (HBsAg) -positive ${ }^{8}$. Studies conducted in the last decade demonstrate variable rates of HBsAg-positivity across different countries and even across different regions within a single country ${ }^{9}$. The natural course of HBV is determined by the interaction between viral replication and host immunity. The HBV can persist even after serological recovery from acute HBV infection. In the presence of lymphoid malignancies such as CLL, in which the immune system is suppressed, there is a risk of HBV reactivation, which is characterized by fluctuating aminotransferase levels ${ }^{10}$.

The cellular and humoral immune responses of CLL patients show multiple defects. These defects may be induced by the disease or the chemotherapeutic agents used in the treatment. Such immune failure is known to be associated with an increase in the frequency of particularly gram-positive and -negative bacterial infections. However, data on the increase in the frequency of zoonoses such as brucellosis and viral infections such as HBV are inconclusive.

This study aims to investigate the frequency of brucellosis and HBV seropositivity in patients followed-up for CLL and compare the results with those of epidemiological studies conducted in the same region.

\section{METHODS}

\section{Patients}

This study evaluated patients with CLL who were followed-up at the Department of Hematology at Yüzüncü Yıl University, Medical Faculty Hospital between 2005 and 2019. Follow-up files of the patients and data from the hospital system were retrospectively reviewed. All patients who were; diagnosed with CLL, aged 18 years or older, treated or untreated for CLL were included in the study. Patients younger than 18 years and patients with incomplete data were excluded from the study. Among all patients; test results of those who had been tested for HBsAg, anti-HBs, and brucellosis were recorded. Demographic data and laboratory results of all patients included in the study were recorded.

\section{Diagnosis of hepatitis $B$ virus and brucellosis}

Serum samples collected from the patients were analyzed to determine the titers of HBsAg and Anti-HBs, which are serologic markers of hepatitis B infection, with the Enzyme Linked Immunosorbent Assay (ELISA) (ARCHITECT i1000 SR Immunoassay Analyzer, Abbott Diagnostics, Germany) method. Brucellosis was investigated using the serum (Wright) agglutination test, which is the most widely used diagnostic test around the world. Titres of $1 / 160$ or higher on this test were considered positive.

\section{Ethics consent}

The study was approved by the research ethics committee of Yüzüncü Yıl University, Faculty of Medicine (date/reference number: 31.01.2018/002). All analyses were performed in accordance with the principles of the Declaration of Helsinki.

\section{Data Analysis}

Statistical analysis of the data was performed using the IBM SPSS 22 (SPSS Inc., Chicago, IL, USA) statistical package program. Descriptive statistics for studied variables (characteristics) were presented as mean, standard deviation, median, minimum and maximum values, and for categorical variables the frequency is expressed as a percentage [n (\%)]. For determining the relationship between groups and categorical variables, the Chi-square test was used. The level of significance was set at $p<0.05$.

\section{RESULTS}

This study included 188 patients diagnosed with CLL, the medical data of whom were 611 
retrospectively reviewed. Of these patients, 56 (29.8\%) were female and 132 (70.2\%) were male. Median patient age was 62 (range: 33-92) years. Complete blood count parameters at diagnosis were as follows: median leukocyte count, 54.4×109/L (5.1-312.3×109/L); median lymphocyte count, $42.3 \times 109 / \mathrm{L} \quad$ (2.8$296.8 \times 109 / \mathrm{L})$; median platelet count, $148 \times 109 / \mathrm{L} \quad(86.3-342.3 \times 109 / \mathrm{L}) ; \quad$ median hemoglobin level, $13.4 \mathrm{~g} / \mathrm{dL}$ (8.5-16.9 g/dL). Demographic data and laboratory results of the patients are presented in Table I.

Table I: Demographic characteristics and laboratory features of patients with chronic lymphocytic leukemia

\begin{tabular}{|c|c|c|}
\hline Parameters & Median & Range \\
\hline \multicolumn{3}{|l|}{ Gender, n (\%) } \\
\hline Female & $56(29.8)$ & \\
\hline Male & $132(70.2)$ & \\
\hline \multicolumn{3}{|l|}{ Age } \\
\hline Female & 61 & $35-90$ \\
\hline Male & 63 & $33-92$ \\
\hline Leukocyte count $\left(\times 10^{9} / \mathrm{L}\right)$ & 54.4 & $2.6-368$ \\
\hline $\begin{array}{l}\text { Lymphocyte count } \\
\left(\times 10^{9} / \mathrm{L}\right)\end{array}$ & 42.3 & $1.1-283$ \\
\hline Platelet count $\left(\times 10^{9} / \mathrm{L}\right)$ & 148 & $24-564$ \\
\hline Hemoglobin level (g/dL) & 13.4 & $5.4-16.7$ \\
\hline $\begin{array}{l}\text { Lactate dehydrogenase } \\
\text { (IU/L) }\end{array}$ & 345 & $82-2114$ \\
\hline Creatinine (mg/dL) & 0.88 & $0.4-2.1$ \\
\hline
\end{tabular}

HBsAg and anti-HBs were assessed in 142 patients. A total of 16 (11.27\%) patients were HBsAg-positive; with $5(3.52 \%)$ positive cases in females and 11 (7.75\%) in males. A total of 105 (73.95\%) patients were Anti-HBs-positive; with $32(22.54 \%)$ positive cases in females and $73(51.41 \%)$ in males.
The serum (Wright) agglutination test was performed on 82 patients. A total of 4 (4.88\%) patients reacted positively to the Wright test; with $3(3.66 \%)$ positive cases in females and 1 $(1.22 \%)$ in males. HBsAg, Anti-HBs and Wright test results of the patients are presented in detail in Table II.

Table II: HBsAg, anti-HBs and Wright test results of tested patients

\begin{tabular}{|l|l|c|c|c|c|c|c|}
\hline \multirow{2}{*}{ Characteristic } & \multicolumn{2}{|c|}{ HBsAg } & \multicolumn{2}{c|}{ Anti-HBs } & \multicolumn{2}{c|}{$\begin{array}{c}\text { Wright } \\
\text { test }\end{array}$} \\
\cline { 3 - 8 } & n & $\%$ & n & $\%$ & n & $\%$ \\
\hline Positive & & & & & & & \\
\hline & Female & 5 & 3.52 & 32 & 22.54 & 3 & 3.66 \\
\hline & Male & 11 & 7.75 & 73 & 51.41 & 1 & 1.22 \\
\hline \multirow{2}{*}{ Negative } & Total & 16 & 11.27 & 105 & 73.95 & 4 & 4.88 \\
& & & & & & & \\
\hline & Female & 28 & 19.72 & 9 & 6.33 & 21 & 25.61 \\
\hline & Male & 98 & 69.01 & 28 & 19.72 & 57 & 69.51 \\
\hline & Total & 126 & 88.73 & 37 & 26.05 & 78 & 95.12 \\
\hline
\end{tabular}

\section{DISCUSSION}

CLL is a disease characterized by an increase in clonal B-cells, which are considered dysfunctional, and a relative decrease in the normal lymphocyte count. CLL patients frequently show autoimmune events due to immune dysfunction and conditions such as immune failure ${ }^{11}$. CLL patients demonstrate various defects associated with the cellular and humoral immune responses. These immune defects may be induced by the disease or by the chemotherapeutic agents used in the treatment. This promotes infections, which are implicated in approximately $50 \%$ of mortality seen in CLL patients ${ }^{12}$. The risk of serious infections rises particularly in the advanced stages of the disease where there is both bone marrow infiltration and therapy-induced immune 
dysfunction ${ }^{13}$. Prevalence rates of bacterial infections such as Streptococcus pneumonia, Staphylococcus aureus and Haemophilus influenza are higher in all CLL patients. Further, cases of herpes zoster associated with Herpes simplex virus and Varicella-zoster virus reactivation are also encountered frequently ${ }^{14}$.

The increased frequency of infections in CLL, which is associated with a high risk of morbidity and mortality, can be reduced by immunization, intravenous immunoglobulin (IVIG), antimicrobial treatment, and the use of granulocyte-colony stimulating factor (G-CSF). Although there are no randomized studies on the use of prophylactic antibiotics, the use of IVIG and G-CSF are recommended on a patientspecific basis ${ }^{15,16}$. Similarly, the frequency of secondary malignancies shows an increase regardless of treatment and this increase in solid malignancies, which can occur as comorbidity, are attributed to the probable presence of immunologic disorders ${ }^{17}$.

Brucellosis has a wide clinical spectrum in both healthy individuals and those with comorbid conditions, and may be asymptomatic or present a fatal clinical picture. Generally, the chief complaint is fever, either alone or with local symptoms, and the progression is more favorable in children than adults with a better response to medication ${ }^{18}$. Acute disease is typically associated with symptoms and findings such as fever, night sweats, arthralgia, myalgia, lumbar pain, headache, dizziness, depression and anorexia ${ }^{19,20}$. However, physical examination findings are quite variable and hepatomegaly, splenomegaly, and lymphadenomegaly may also be encountered6. Among the hematologic abnormalities seen in brucellosis; anemia, thrombocytopenia, leukopenia, pancytopenia, and disseminated intravascular coagulation are relatively more common $^{21}$. These symptoms and findings may be mistaken for the general symptoms and findings of CLL. Particularly in regions where brucellosis is endemic or common, a differential diagnosis is vital for patients who present with these clinical symptoms and findings.

The seroprevalence of brucellosis in our country varies between $3-14 \%$ according to recent studies. The Eastern Anatolia region, which includes the province of Van, is among the regions where the disease is most prevalent along with the Southeastern Anatolia and Central Anatolia regions ${ }^{22}$. In the present study, 82 patients were tested for brucellosis using the serum (Wright) agglutination test and the total rate of positivity was $4.88 \%$, in congruence with the literature.

The prevalence of hepatitis B virus infection can vary across regions within the same country depending on the risk groups. In a large case series by Ekinci et al. that involved 108.368 individuals, the rate of HBsAg positivity in Van and surrounding regions was determined as $0.09 \% 9$. In the present study, a total of 16 (11.27\%) patients were HBsAg-positive; with 5 (3.52\%) positive cases in females and 11 $(7.75 \%)$ in males. These rates were much higher compared with the results of studies conducted on the normal population in the same region. This suggests that the risk of HBV transmission is elevated due to the immune defect caused by CLL or the immunosuppressive picture induced by the medication used in the treatment, or that viral reactivation is involved.

In conclusion, the immune system disorders that develop due to the nature of CLL make the patient more vulnerable to infections. Accordingly, many patients lose their lives due to a clinical picture of severe infection. Based on the present study, we think that Brucellosis, which presents with clinical findings that resemble the B symptoms of CLL and the prevalence of which is fairly high in regions of high endemicity, must be eliminated based on laboratory findings prior to the treatment. Also, hepatitis B reactivation results in serious clinical conditions during the treatment of CLL 
patients. Our aim was to stress the importance of HBV as one of the viral agents that are recommended to be screened prior to the treatment and the significantly higher frequency of HBV among CLL patients compared with the normal population.

Ethics Committee Approval: The study was approved by the research ethics committee of Yüzüncü Yıl University, Faculty of Medicine (date/reference number: 31.01.2018/002). All analyses were performed in accordance with the principles of the Declaration of Helsinki.

Declaration of Conflicting Interests: The authors declare that they have no conflict of interest.

Financial Disclosure: No financial support was received.

\section{REFERENCES}

1. Hallek M. Chronic lymphocytic leukemia: 2017 update on diagnosis, risk stratification, and treatment. Am J Hematol. 2017; 92: 946-65.

2. Swerdlow SH, Campo E, Pileri SA, et al. The 2016 revision of the World Health Organization classification of lymphoid neoplasms. Blood. 2016; 127: 2375-90.

3. Demir C, Kara E, Ekinci Ö, et al. Clinical and Laboratory Features of CD5-Negative Chronic Lymphocytic Leukemia. Med Sci Monit. 2017; 23: 2137-42.

4. Shanafelt TD, Rabe KG, Kay NE, et al. Age at diagnosis and the utility of prognostic testing in patients with chronic lymphocytic leukemia. Cancer. 2010; 116: 477787.

5. Franco MP, Mulder M, Gilman RH, et al. Human brucellosis. Lancet Infect Dis. 2007; 7: 775-86.

6. Dean AS, Crump L, Greter H, et al. Global burden of human brucellosis: a systematic review of disease frequency. PLoS Negl Trop Dis. 2012; 6: e1865.

7. Mantur BG, Amarnath SK, Shinde RS. Review of clinical and laboratory features of human brucellosis. Indian J Med Microbiol. 2007; 25: 188-202.

8. Ott JJ, Stevens GA, Groeger J, et al. Global epidemiology of hepatitis B virus infection: new estimates of agespecific HBsAg seroprevalence and endemicity. Vaccine. 2012; 30: 2212-9.
9. Ekinci O, Kara O, Demircioglu S, et al. Evaluation of transfusion transmitted infections and distribution of $\mathrm{ABO}$ and $\mathrm{Rh}$ blood groups in donors in Eastern Turkey. Ann Med Res. 2019; 26: 2088-92.

10. Gupta S, Govindarajan S, Fong TL, et al. Spontaneous reactivation in chronic hepatitis $\mathrm{B}$ : patterns and natural history. J Clin Gastroenterol. 1990; 12: 562-8.

11. Demir C, Ekinci Ö. Clinical and serological autoimmune complications in chronic lymphocytic leukemia. Wien Klin Wochenschr. 2017; 129: 552-7.

12. Tsiodras S, Samonis G, Keating MJ, et al. Infection and immunity in chronic lymphocytic leukemia. Mayo Clin Proc. 2000; 75: 1039-54.

13. Perkins JG, Flynn JM, Howard RS, et al. Frequency and type of serious infections in fludarabine-refractory B-cell chronic lymphocytic leukemia and small lymphocytic lymphoma: implications for clinical trials in this patient population. Cancer. 2002; 94: 2033-9.

14. Morrison VA. Management of infectious complications in patients with Chronic lymphocytic leukemia. Hematology Am Soc Hematol Educ Program. 2007: 3328.

15. Griffiths H, Brennan V, Lea J, et al. Crossover study of immunoglobulin replacement therapy in patients with low-grade B-cell tumors. Blood. 1989; 73: 366-8.

16. Lyman GH, Kleiner JM. Summary and comparison of myeloid growth factor guidelines in patients receiving cancer chemotherapy. Cancer Treat Res. 2011; 157: 14565.

17. Ekinci O, Dogan A, Demircioglu S, et al. Secondary primary malignancy presence and related factors in chronic lymphocytic leukemia. Med Sci Discov. 2018; 5: 106-9.

18. Doganay M, Aygen B. Human brucellosis: an overview. Int J Infect Dis. 2003; 7: 173-82.

19. Bilek H, Alanbayı Ü, Bal T. An Acute Brucellosis Case Presented with Pancytopenia and Hepatitis. Dicle Med J. 2018; 45: 103-7.

20. Dede G, Dede O, Kapmaz M, et al. Two cases of brucellosis epididymo-orchitis. Dicle Med J. 2015; 42: 80-82.

21. Pappas G, Akritidis N, Bosilkovski M, et al. Brucellosis. N Engl J Med. 2005; 352: 2325-36.

22. Buzgan $\mathrm{T}$, Karahocagil MK, Irmak $\mathrm{H}$, et al. Clinical manifestations and complications in 1028 cases of brucellosis: a retrospective evaluation and review of the literature. Int J Infect Dis. 2010; 14: e469-78. 